It is not yet clear whether such efforts will be enough for genomics. Given the biological complexities involved, applying knowledge of the human genome to health may well require a community-wide effort as determined and as systematic as was the project to sequence it in the first place.

That effort would need to solve a long-standing mismatch: the rapidly increasing ease of gathering genomic data versus the continuing difficulty of establishing what the genetic elements actually do. One intriguing experiment in high-throughput functional analysis appears on page 721 , where the authors detail how they systematically disabled each of the 21,000 protein-coding genes in human cells and then captured and processed microscope images of the resulting cellular behaviour.

The effort would also require even more imaginative ways to visualize and draw meaning from the flood of genomic and molecular data (see page 678). It would require interdisciplinary teams that can provide know-how not just in research, but in the issues such as intellectual property, informed consent, finance and regulatory bureaucracy that are needed to keep discoveries moving through the agonies of clinical development.

\section{A new row to hoe}

\section{The time is right to revitalize US agricultural research.}

$\mathrm{n}$ nations where food is plentiful, it is easy to take that abundance for granted. In the United States, for example - a country rich in corn fields and pasturelands, and where shops overflow with cheap produce - agricultural research has languished for years under comparatively low budgets and disorganized funding priorities. In the 2009 economic stimulus bill, for example, the National Science Foundation received a $\$ 3$-billion boost and the National Institutes of Health got $\$ 10$ billion - but the Department of Agriculture's internal research programme was allocated just $\$ 176$ million, all of which was restricted to improving facilities.

It is heartening, then, that the administration of President Barack Obama has begun a much-needed overhaul of the nation's agricultural-research programme. The groundwork was laid in June 2008, when US Congress mandated the creation of a National Institute of Food and Agriculture (NIFA) within the agriculture department. Under the leadership of Roger Beachy, whom Obama appointed in September last year, the new agency has taken over, expanded and revitalized the department's long-standing competitive grants programme, now called the Agriculture and Food Research Initiative.

Last week, NIFA released its eagerly anticipated first call for grant proposals, and the changes are indeed dramatic. In striking contrast to the smaller, two-year individual grants that were the mainstay of the programme, NIFA's offerings now include a series of five-year 'coordinated agricultural projects' of up to $\$ 45$ million for collaborative, interdisciplinary research. NIFA has defined its funding priorities much more clearly than its predecessor did, and it has aligned them with a series of 'societal challenges' that include climate change, bioenergy
Perhaps it would even require an explicit challenge to foster fervour and competition. For example, the X-Prize Foundation of Playa Vista, California, is offering a prize of US $\$ 10$ million to the first group to sequence 100 human genomes in ten days. Why shouldn't some organization offer a reward and kudos for, say, the next geneticsbased cancer drug to go from basic genomic data to approved therapy within ten years? True, real-world therapies are unlikely to have metrics as clear as those in genome sequencing, in which progress can be measured in base pairs read per day and there is a well-defined end point. But the need is no less urgent, and the collective will to reach such goals should be no less intense.

More than anything, the race to sequence the human genome proved that researchers comfortable in their individual pursuits are capable of incredible cohesion, focus and breathtaking speed. They rewrote the research rule-book, broke with the conventions of individual academic goals and left the public with the sense that anything is scientifically possible. The ten years since have brought astounding technological and intellectual advances. But ten years from now, when the story of the genome's first two decades is being told, it should include equally astounding applications to human health.

and childhood obesity. The agency has also declared that the success of the programmes will be measured not just by scientific publications, but by real progress towards solving these challenges, such as reducing the amount of energy, nitrogen fertilizer and water used in agriculture by $10 \%$ by 2030 . It has also introduced new fellowship and outreach programmes in an effort to stimulate the dwindling pipeline of young talent entering the field.

The overall intent, says Beachy, is to raise the status of the nation's agricultural research, hopefully drawing attention and support from the nation's lawmakers in the process. With just \$262 million available for the first round of grants, the Agriculture and Food Research Initiative is still financially constrained compared with other US science agencies. But the structure of its competitive grants programme is an important step towards maximizing the impact of the funds that it does have.

The transition has not pleased everyone. News of Beachy's appointment caused a stir among opponents of genetically modified crops, who noted that he has voiced support for such crops in the past. Beachy has maintained that NIFA will also support small farms and traditional crop-breeding programmes, and the first call for proposals does seem to be doing this. But the strength of that support will become clear only after the grants have been made.

Meanwhile, many long-time agricultural researchers are feeling unsettled by the abruptness of the changes. Some are dismayed to find that their favourite funding programmes have been cut. Others find the new structure too prescriptive, and worry that it leaves little room for creative approaches. These are legitimate concerns, and NIFA should follow through with its promise to solicit input from the community before it crafts next year's proposals.

Nevertheless, the community should seize this opportunity to tackle big problems. Growing pains are inevitable, but the shake-up has the potential to rejuvenate the field at a time when its talents are desperately needed. 